DER MARXISMUS 



\section{DER MARXISMUS}

UND DAS

\section{WESEN DER SOZLALEN FRAGE}

vON

\section{PAUL WEISENGRÜN.}

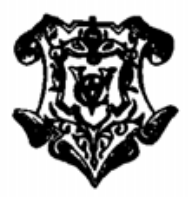

LEIPZIG,

VERLAG VON VEIT \& COMP.

1900. 
Druck von Metzger \& Wittig in Leipzig. 